Article

\title{
The Antimicrobial Activity of Annona emarginata (Schltdl.) H. Rainer and Most Active Isolated Compounds against Clinically Important Bacteria
}

\author{
Juan G. Dolab ${ }^{1}$ (1) , Beatriz Lima ${ }^{2}$, Ewelina Spaczynska ${ }^{3}$, Jiri Kos ${ }^{4}$, Natividad H. Cano ${ }^{2}$, \\ Gabriela Feresin ${ }^{2}$, Alejandro Tapia ${ }^{2}$, Francisco Garibotto ${ }^{1,5}$, Elisa Petenatti ${ }^{1}$ (D), \\ Monica Olivella ${ }^{1}$, Robert Musiol ${ }^{3}$, Josef Jampilek ${ }^{4, *(D)}$ and Ricardo D. Enriz ${ }^{1,5, *}$ \\ 1 Faculty of Chemistry Biochemistry and Pharmacy, National University of San Luis, Chacabuco 917, \\ 5700 San Luis, Argentina; juandolab@gmail.com (J.G.D.); fgaribotto@gmail.com (F.G.); \\ elipete@unsl.edu.ar (E.P.); olivellamonica@gmail.com (M.O.) \\ 2 Institute of Biotechnology-Institute of Basic Sciences, National University of San Juan, Av. Libertador \\ General San Martin 1109, 5400 San Juan, Argentina; blima@unsj.edu.ar (B.L.); \\ natividadhc17@hotmail.com (N.H.C.); gferesin@unsj.edu.ar (G.F.); atapia@unsj.edu.ar (A.T.) \\ 3 Institute of Chemistry, University of Silesia, 75 Pulku Piechoty 1, 41500 Chorzow, Poland; \\ ewelina.spaczynska@gmail.com (E.S.); robert.musiol@us.edu.pl (R.M.) \\ 4 Department of Pharmaceutical Chemistry, Faculty of Pharmacy, Comenius University, Odbojarov 10, \\ 83232 Bratislava, Slovakia; jirikos85@gmail.com \\ 5 Multidisciplinary Institute of Biological Research IMIBIO-CONICET, Chacabuco 917, \\ 5700 San Luis, Argentina \\ * Correspondence: josef.jampilek@gmail.com (J.J.); denriz@unsl.edu.ar (R.D.E.); Tel.: +421-250-117-229 (J.J.); \\ +54-0266-4520300 (R.D.E.)
}

Received: 24 April 2018; Accepted: 10 May 2018; Published: 16 May 2018

Abstract: Annona emarginata (Schltdl.) H. Rainer, commonly known as "arachichú", "araticú", "aratigú", and "yerba mora", is a plant that grows in Argentina. Infusions and decoctions are used in folk medicine as a gargle against throat pain and for calming toothache; another way to use the plant for these purposes is chewing its leaves. Extracts from bark, flowers, leaves, and fruits from A. emarginata were subjected to antibacterial assays against a panel of Gram $(+)$ and Gram $(-)$ pathogenic bacteria according to Clinical and Laboratory Standards Institute protocols. Extracts from the stem bark and leaves showed moderate activity against the bacteria tested with values between 250-1000 $\mu \mathrm{g} / \mathrm{mL}$. Regarding flower extracts, less polar extracts (hexane, dichloromethane) showed very strong antibacterial activity against methicillin-sensitive Staphylococcus aureus ATCC 25923 and methicillin-resistant S. aureus ATCC 43300 with values between 16-125 $\mu \mathrm{g} / \mathrm{mL}$. Additionally, hexane extract showed activity against Klebsiella pneumoniae $(\mathrm{MIC}=250 \mu \mathrm{g} / \mathrm{mL}$ ). The global methanolic extract of the fruits (MeOHGEF) was also active against the three strains mentioned above, with MICs values $250-500 \mu \mathrm{g} / \mathrm{mL}$. Bioassay-guided fractionation of MeOHGEF led to the isolation of a new main compound-(R)-2-(4-methylcyclohex-3-en-1-yl)propan-2-yl (E)-3-(4-hydroxyphenyl)acrylate (1). The structure and relative configurations have been determined by means of 1D and 2D NMR techniques, including COSY, HMQC, HMBC, and NOESY correlations. Compound 1 showed strong antimicrobial activity against all Gram $(+)$ species tested (MICs $=3.12-6.25 \mu \mathrm{g} / \mathrm{mL}$ ). In addition, the synthesis and antibacterial activity of some compounds structurally related to compound $\mathbf{1}$ (including four new compounds) are reported. A SAR study for these compounds was performed based on the results obtained by using molecular calculations.

Keywords: Annona emarginata; (R)-2-(4-methylcyclohex-3-en-1-yl)propan-2-yl (E)-3-(4-hydroxyphenyl)acrylate; antibacterial activity; Staphylococcus aureus; structure-activity relationships 


\section{Introduction}

Some genera from the family Annonaceae are an important natural source of products with antifungal [1], bactericidal [2], pesticidal [3], herbicidal [4], antimalarial [5], antiprotozoal [6], and cytostatic [7,8] activity, especially some chemically isolated components (primarily from seeds, leaves, and bark). These compounds include flavonoids, alkaloids, and acetogenins. This family is widely distributed in tropical and subtropical regions around the world in diversity of habitats (forests, scrub, and grassland), with higher prevalence in rain forests. In general, representatives of the family are shrubs, but it is also possible to find dwarf shrubs or small trees and, rarely, canopy trees or lianas among them. The Annona genus comprises ca. 160 species from the tropical and subtropical areas, from both hemispheres. Four species grow mainly in Argentina: Annona emarginata (Schltdl.) H. Rainer (=Rollinia emarginata Schltdl.), A. neosalicifolia H. Rainer (=Rollinia salicifolia Schltdl.), A. nutans (R.E. Fr.), and A. rugulosa (Schltdl.) H. Rainer. Previous studies related to ethnopharmacological use have shown that the infusions and decoctions of the leaves of $A$. emarginata, commonly known as "arachichú", "araticú", "aratigú", and "yerba mora", are used in folk medicine as a gargle against throat pain and for calming the toothache. Another way it is used is by absorbing juice produced by chewing the leaves [9,10]. Antiprotozoal [11] and antifeedant [12] properties have been reported. Regarding its chemical composition, rolliniastatin-1, sylvaticin, squamocin, rollidecin B, lirioresinol B, liriodenine [11]; vomifoliol, dehydrovomifoliol, blumenol C, loliolide, 7-epiloliolide, vanillin, dihydroactinolide [12]; ursolic acid, oleanolic acid, 8-trans- $p$-coumaroyloxy- $\alpha$-terpineol, quercetin-3-O- $\alpha$-L-arabinopyranosyl $(1 \rightarrow 2)-\alpha$-L-rhamnopyranoside [13]; alkaloids including two aporphines (-)-anonaine, (-)-asimilobine and one benzyltetrahydroisoquinoline, (+)-reticuline [14], and cyanogenic glycosides [15] have been previously isolated from its aerial parts. Resistance to antimicrobials is a problem that increasingly threatens the world population [16]. The World Health Organization established as "priority pathogens" those resistant to antibiotics, which include 12 families of bacteria most dangerous to human health, the so-called "superbugs". Among them, especially the threat posed by Gram (-) bacteria resistant to multiple antibiotics is highlighted. Among the Gram (+) bacteria, methicillin-resistant Staphylococcus aureus (MRSA) [17] is one of the most important. Thus, the development of new molecules, alternative strategies, and prevention and control measures is necessary to avoid this problem.

The main objective of this work is to determine the antibacterial effect of different extracts of A. emarginata (Schltdl.) H. Rainer, which is widely used in folk medicine in the northeast part of Argentine. Another goal is to try to determine which active compound is responsible for such activity. Thus, this work has been done in several stages. In the first step, the antimicrobial properties of extracts of A. emarginata were studied, and the bioassay-guided isolation of its most active compound was made. The compound was tested against an extended panel of both standardized and clinical opportunistic pathogenic bacteria. The species were selected to include Gram (+) and Gram (-) species of the most common human pathogens. Once the structure of the compound responsible for the antibacterial activity was determined, some structurally related compounds were synthesized. Finally, based on molecular calculations, we performed a study of the structure-activity relationships of antibacterial compounds of the different series reported here.

\section{Results and Discussion}

\subsection{Antimicrobial Evaluation of A. emarginata Extracts and Its Active Ingredient}

The extracts from the stem bark and leaves of A. emarginata showed moderate activity against the bacteria tested, with values between 250 and $1000 \mu \mathrm{g} / \mathrm{mL}$ (Table 1). Regarding flower extracts, the less polar (hexane, dichloromethane) extracts, HFIE and DCMFIE, showed very strong antibacterial activity against methicillin-sensitive S. aureus (MSSA) ATCC 25923 and methicillin-resistant S. aureus (MRSA) ATCC 43300, with values between 16 and $125 \mu \mathrm{g} / \mathrm{mL}$. Additionally, hexane extract showed activity against Klebsiella pneumoniae (MIC $=250 \mu \mathrm{g} / \mathrm{mL}$ ). The global methanolic extract from the fruits 
(MeOHGFE) was also active against the three strains mentioned above, with minimum inhibitory concentration (MIC) values between $250-500 \mu \mathrm{g} / \mathrm{mL}$. In order to identify bioactive compounds, a bioassay-guided fractionation of the MeOHGFE was performed.

Table 1. Antibacterial activity (MIC $(\mu \mathrm{g} / \mathrm{mL})$ ) of extracts of A. emarginata (Annonaceae).

\begin{tabular}{|c|c|c|c|c|c|c|c|}
\hline \multirow{2}{*}{\multicolumn{2}{|c|}{ Extracts }} & \multicolumn{6}{|c|}{$\operatorname{MIC}(\mu \mathrm{g} / \mathrm{mL})$} \\
\hline & & MSSA & MRSA & $\begin{array}{c}\text { E. coli ATCC } \\
25922\end{array}$ & E. coli LM2 & K. pneumoniae & Salmonella sp. \\
\hline \multirow{4}{*}{ Stem bark } & HBE & $>1000$ & $>1000$ & 250 & 500 & $>1000$ & 1000 \\
\hline & DCMBE & 1000 & $>1000$ & 500 & $>1000$ & 1000 & 250 \\
\hline & EtAcOBE & 500 & 1000 & 500 & 500 & $>1000$ & 500 \\
\hline & МeOHBE & 500 & 500 & 1000 & 1000 & $>1000$ & 1000 \\
\hline \multirow{4}{*}{ Leaves } & HLE & 500 & 250 & $>1000$ & $>1000$ & $>1000$ & 500 \\
\hline & DCMLE & 500 & 500 & $>1000$ & 1000 & 1000 & 500 \\
\hline & EtAcOLE & 500 & 500 & $>1000$ & $>1000$ & 250 & 500 \\
\hline & MeOHLE & $>1000$ & $>1000$ & 500 & 500 & 500 & 500 \\
\hline \multirow{4}{*}{ Flowers } & HFlE & 125 & 125 & $>1000$ & $>1000$ & 250 & 1000 \\
\hline & DCMFIE & 62.5 & 16 & $>1000$ & $>1000$ & 1000 & $>1000$ \\
\hline & EtAcOFlE & 250 & 250 & 1000 & $>1000$ & 500 & $>1000$ \\
\hline & MeOHFIE & $>1000$ & $>1000$ & 1000 & 1000 & $>1000$ & $>1000$ \\
\hline Fruits & MeOHGFE & 500 & 500 & $>1000$ & $>1000$ & 250 & $>1000$ \\
\hline \multicolumn{2}{|c|}{ cefotaxime } & 0.5 & 0.5 & 1.9 & 0.5 & 15 & 12.5 \\
\hline
\end{tabular}

HBE: hexane bark extract; DCMBE: dichloromethane bark extract; EtOAcBE: ethyl acetate bark extract; MeOHBE: methanol bark extract; HLE: hexane leaf extract; DCMLE: dichloromethane leaf extract; EtOAcLE: ethyl acetate leaf extract; MeOHLE: methanol leaf extract; HFlE: hexane flower extract; DCMFlE: dichloromethane flower extract; EtOAcFlE: ethyl acetate flower extract; MeOHFlE: methanol flower extract; MeOHGFE: methanol global fruit extract.

Tables 2 and 3 show the antimicrobial activity of fractions and subfractions of the MeOHGFE. Fraction $\mathrm{F}_{3}$ displayed the strongest antibacterial activity (Table 2) against MSSA, MRSA, Escherichia coli ATCC $25922(\mathrm{MIC}=500 \mu \mathrm{g} / \mathrm{mL})$, and K. pneumoniae $(\mathrm{MIC}=125 \mu \mathrm{g} / \mathrm{mL})$. To gain further information about their activity spectrum against Gram (+) strains, we added a panel of clinical isolates obtained from human patients (coagulase negative Staphylococcus aureus 502, Streptococcus pyogenes and Streptococcus agalactiae) (Tables 3 and 4). Fraction $\mathrm{F}_{3}$ was further percolated on Sephadex LH-20 affording 5 subfractions (I-V). One of them, subfraction $\mathrm{F}_{\mathrm{IV}}$, showed strong antibacterial activity with $\mathrm{MIC}=16 \mu \mathrm{g} / \mathrm{mL}$ against all the Gram $(+)$ bacteria tested, except for coagulase negative $S$. aureus $502(\mathrm{MIC}=31.2 \mu \mathrm{g} / \mathrm{mL})$, Escherichia coli LM2 (MIC = $125 \mu \mathrm{g} / \mathrm{mL})$, and K. pneumoniae (MIC $=250 \mu \mathrm{g} / \mathrm{mL}$, respectively). On the basis of the previous results, subfraction $\mathrm{F}_{\mathrm{IV}}$ was successively purified by Sephadex LH-20 and silica gel column, affording the main antibacterial compound $\mathbf{1}$ (Figure 1). As we expected, compound 1 showed stronger antimicrobial activity against both Gram $(+)$ ATCC strains with MICs $=3.12-6.25 \mu \mathrm{g} / \mathrm{mL}$, and the expanded panel strains were also sensitive to this compound with MICs value equal $3.12 \mu \mathrm{g} / \mathrm{mL}$ (Table 4). In contrast, compound 2 (see below) was practically inactive. 
Table 2. Antibacterial activity $(\mathrm{MIC}(\mu \mathrm{g} / \mathrm{mL}))$ of fractions $\mathrm{F}_{1}-\mathrm{F}_{6}$ from MeOHGEF.

\begin{tabular}{|c|c|c|c|c|c|c|c|}
\hline \multirow{2}{*}{\multicolumn{2}{|c|}{ Extracts }} & \multicolumn{6}{|c|}{$\operatorname{MIC}(\mu \mathrm{g} / \mathrm{mL})$} \\
\hline & & \multirow{2}{*}{$\begin{array}{c}\text { MSSA } \\
500 \\
\end{array}$} & \multirow{2}{*}{$\begin{array}{c}\text { MRSA } \\
500 \\
\end{array}$} & \multirow{2}{*}{$\begin{array}{c}\text { E. coli ATCC } \\
25922 \\
>1000\end{array}$} & \multirow{2}{*}{$\begin{array}{c}\text { E. coli LM2 } \\
>1000\end{array}$} & \multirow{2}{*}{$\begin{array}{c}\text { K. pneumoniae } \\
250\end{array}$} & \multirow{2}{*}{$\begin{array}{c}\text { Salmonella sp. } \\
>1000\end{array}$} \\
\hline $\mathrm{MeO}$ & & & & & & & \\
\hline & $F_{1}$ & $>1000$ & $>1000$ & $>1000$ & $>1000$ & $>1000$ & $>1000$ \\
\hline & $\mathrm{F}_{2}$ & 500 & 250 & $>1000$ & $>1000$ & $>1000$ & $>1000$ \\
\hline MeOHGFE & $F_{3}$ & 500 & 500 & 500 & $>1000$ & 125 & $>1000$ \\
\hline \multirow[t]{3}{*}{ Fractions } & $\mathrm{F}_{4}$ & 1000 & 1000 & 1000 & 125 & 1000 & $>1000$ \\
\hline & $\mathrm{F}_{5}$ & 500 & 500 & 1000 & 250 & 125 & $>1000$ \\
\hline & $\mathrm{F}_{6}$ & 250 & 500 & 250 & 250 & $>1000$ & $>1000$ \\
\hline \multicolumn{2}{|c|}{ cefotaxime } & 0.5 & 0.5 & 1.9 & 0.5 & 15 & 12.5 \\
\hline
\end{tabular}

MeOHGFE: methanol global extract fruit; F1 (200 mg; hex 100\%), F2 (115 mg; 50:50\% H:DCM), F3 (1200 mg; 90:10\% DCM:EtOAc), F4 (187.7 mg 80:20\% DCM:EtOAc), F5 (155 mg; 70:30\% DCM:EtOAc), and F6 (137 mg; EtOAc100\%).

Table 3. Antibacterial activity $(\mathrm{MIC}(\mu \mathrm{g} / \mathrm{mL}))$ of subfractions $\mathrm{F}_{\mathrm{I}-\mathrm{V}}$ from $\mathrm{F}_{3}$.

\begin{tabular}{|c|c|c|c|c|c|c|c|c|c|c|}
\hline \multirow{2}{*}{\multicolumn{2}{|c|}{ Extracts }} & \multicolumn{9}{|c|}{ MIC ( $\mu \mathrm{g} / \mathrm{mL})$} \\
\hline & & MSSA & MRSA & SA & SP & SAG & EC & ELM & KP & Ssp \\
\hline \multicolumn{2}{|c|}{ MeOHGFE Fraction $F_{3}$} & 500 & 500 & 500 & 250 & 250 & 500 & $>1000$ & 125 & $>1000$ \\
\hline \multirow{5}{*}{$\begin{array}{c}F_{3} \\
\text { subfractions }\end{array}$} & Subfraction I & $>250$ & $>250$ & $>250$ & $>250$ & $>250$ & $>250$ & $>250$ & $>250$ & $>250$ \\
\hline & Subfraction II & $>250$ & $>250$ & $>250$ & $>250$ & $>250$ & 250 & $>250$ & $>250$ & $>250$ \\
\hline & Subfraction III & $>250$ & $>250$ & $>250$ & $>250$ & $>250$ & $>250$ & 250 & $>250$ & $>250$ \\
\hline & Subfraction IV & 16 & 16 & 31.2 & 16 & 16 & $>250$ & 125 & 250 & $>250$ \\
\hline & Subfraction $\mathbf{V}$ & 62.5 & 62.5 & 62.5 & 62.5 & 62.5 & $>250$ & $>250$ & $>250$ & $>250$ \\
\hline \multicolumn{2}{|c|}{ cefotaxime } & 0.5 & 0.5 & 0.5 & 0.25 & 0.25 & 1.9 & 0.5 & 15 & 12.5 \\
\hline
\end{tabular}

MSSA = methicillin-sensitive Staphylococcus aureus ATCC 25923, MRSA = methicillin-resistant Staphylococcus aureus ATCC 43300, SA = coagulase negative Staphylococcus aureus 502, SP = Streptococcus pyogenes, SAG = Streptococcus agalactiae, $\mathrm{EC}=$ Escherichia coli $\mathrm{ATCC} 25922, \mathrm{ELM}=$ Escherichia coli LM2, KP = Klebsiella pneumoniae, $\mathrm{Ssp}=$ Salmonella sp.

Table 4. Antibacterial activity (MIC $[\mu \mathrm{g} / \mathrm{mL}]$ ) of compound 1 (isolated from subfraction $\mathrm{F}_{\mathrm{IV}}$ ) and compounds $2-7$ obtained by synthesis.

\begin{tabular}{ccccccccc}
\hline \multirow{2}{*}{ Comp. } & \multicolumn{7}{c}{ MIC $(\mu \mathrm{g} / \mathbf{m L})$} \\
\cline { 2 - 9 } & MSSA & MRSA & SA & SP & SAG & EC & ELM & KP \\
\hline $\mathbf{1}$ & 4 & 6.25 & 3.12 & 3.12 & 3.12 & $>50$ & 50 & 50 \\
$\mathbf{2}$ & $>50$ & $>50$ & $>50$ & $>50$ & $>50$ & $>50$ & $>50$ & $>50$ \\
$\mathbf{3}$ & 50 & 50 & 50 & 50 & 50 & $>50$ & $>50$ & $>50$ \\
$\mathbf{4}$ & $>50$ & $>50$ & $>50$ & $>50$ & $>50$ & $>50$ & $>50$ & $>50$ \\
$\mathbf{5}$ & 50 & $>50$ & 25 & 25 & 50 & $>50$ & $>50$ & $>50$ \\
$\mathbf{6}$ & 25 & 50 & 50 & 50 & 50 & $>50$ & 25 & $>50$ \\
$\mathbf{7}$ & 12.5 & 50 & 12.5 & 25 & 12.5 & $>50$ & 12.5 & $>50$ \\
CEF & 0.5 & 0.5 & 0.5 & 0.25 & 0.25 & 1.9 & 0.5 & 15 \\
\hline
\end{tabular}

MSSA = methicillin-sensitive Staphylococcus aureus ATCC 25923, MRSA = methicillin-resistant Staphylococcus aureus ATCC 43300, SA = coagulase negative Staphylococcus aureus 502, SP = Streptococcus pyogenes, SAG = Streptococcus agalactiae, $\mathrm{EC}=$ Escherichia coli $\mathrm{ATCC}$ 25922, $\mathrm{ELM}=$ Escherichia coli $\mathrm{LM} 2, \mathrm{KP}=$ Klebsiella pneumoniae, $\mathrm{CEF}=$ cefotaxime.

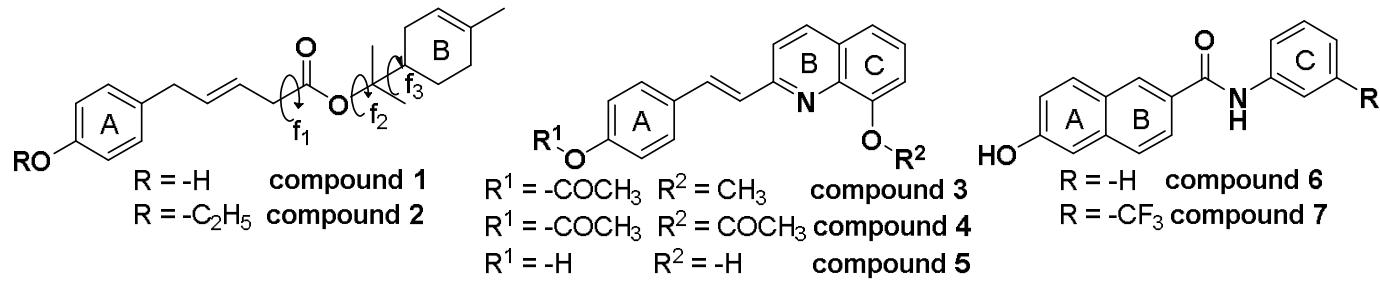

Figure 1. Structural features of compounds studied. Torsional angles are shown for compound $\mathbf{1 .}$ 


\subsection{Natural Lead Structure}

The strongest antimicrobial subfraction IV was successively chromatographed on silica gel to afford pure compound $\mathbf{1}$, which was identified by its spectroscopic data, including ${ }^{1} \mathrm{H},{ }^{13} \mathrm{C}-\mathrm{NMR}$, and HR-EIMS spectra as (R)-2-(4-methylcyclohex-3-en-1-yl)propan-2-yl (E)-3-(4-hydroxyphenyl)acrylate (1), see Figure 1 and spectra in Supplementary Material. The relevant NOESY correlations (Figure 2), a strong positive Cotton effect observed in the CD spectrum and spectroscopic data, which are in partial agreement with those previously published for the compound 9-trans- $p$-coumaroyloxy- $\alpha$-terpineol, isolated from Haplopappus taeda [18], support the structure and absolute configuration proposed in Figure 2. In addition, (DFT) (B3LYP/6-31G (d)) calculations suggest that this structure is $0.46 \mathrm{Kcal} / \mathrm{mol}$ more stable than its isomeric form, giving additional support to the experimental data.

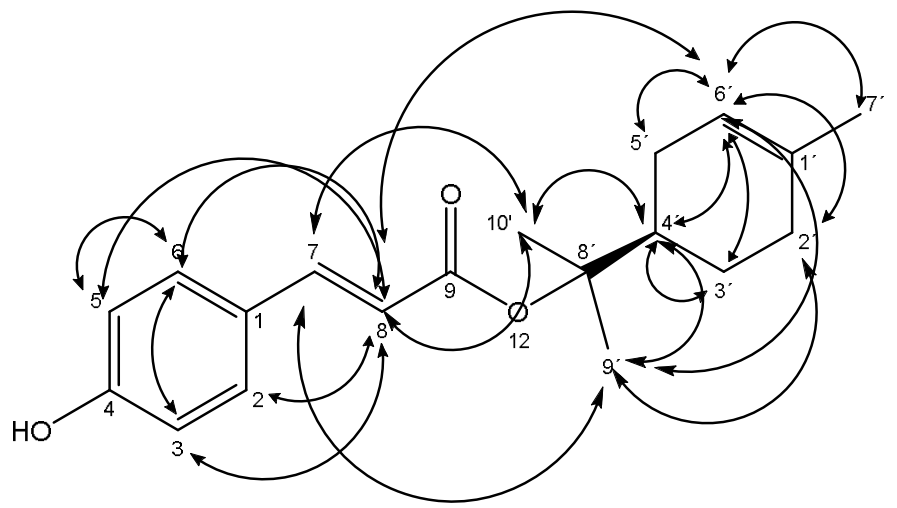

Figure 2. Key NOESY correlations of compound $\mathbf{1}$

\subsection{Synthetic Analogues}

Observing the structure of compound 1, it is interesting to note that the moiety having the aromatic ring corresponds to a structure very similar to that of $p$-coumaric and caffeic acids. Previously, it was reported that analogues of $p$-coumaric and caffeic acids have significant antibacterial and antifungal activities [19,20]. In fact, several phenolic compounds and derivatives possessing antifungal effects have been reported. For example, gallic acid has been reported to prevent aflatoxin biosynthesis by Aspergillus flavus [21]. Two compounds of natural origin, 1-(3'-methoxypropanoyl)-2,4,5-trimethoxybenzene and 2-(2Z)-(3-hydroxy-3,7dimethylocta-2,6-dienyl)-1,4-benzenediol, isolated from the root bark of Cordia alliodora, have been also reported as antifungal and larvicidal compounds [22]. In turn, Kim et al. [23] reported antifungal effects of several phenolic compounds, including cinnamic, $m$-coumaric, $p$-coumaric, and caffeic acids; therefore, the significant antibacterial activity found for compound $\mathbf{1}$ should not be so surprising.

At this stage of the study, efforts were focused on finding new compounds structurally related to lead compound 1 that may have antibacterial activity. First, (R)-2-(4-methylcyclohex-3-en-1-yl)propan-2-yl (E)-3-(4-ethoxyphenyl)acrylate (2) was obtained by a simple modification of compound 1, see Scheme 1. Interestingly, compound 2 was devoid of antibacterial activity displaying MICs values $>50 \mu \mathrm{g} / \mathrm{mL}$. It should be noted that the only structural difference between compounds $\mathbf{1}$ and $\mathbf{2}$ is the ethylation of the hydroxyl group of compound $\mathbf{1}$. 
<smiles>CCOc1ccc(/C=C/C(=O)OC(C)(O)c2ccc(F)cc2)cc1</smiles>

Scheme 1. (R)-2-(4-Methylcyclohex-3-en-1-yl)propan-2-yl (E)-3-(4-ethoxyphenyl)acrylate (2)-

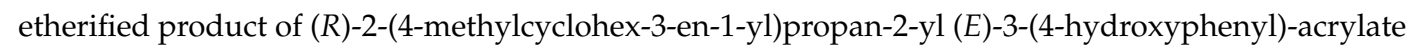
(1). Reagents and conditions: (a) $t$ - $\mathrm{BuOK}, \mathrm{DMSO}, \mathrm{CH}_{3} \mathrm{CH}_{2} \mathrm{I}, 30 \mathrm{~min}$.

Then, compounds 3-5 were synthesized, in which the first moiety of compound $\mathbf{1}$ was maintained, while the second part (4-hydroxyphenyl) of the molecule was replaced by a fused ring (rings A and B) of the quinoline scaffold (see Figure 1). Styrylquinoline derivatives 3 and 4 were prepared by condensation of the quinoline derivative with an appropriate aldehyde in a mixture of acetic anhydride/acetic acid. 2-[2-(4-Hydroxyphenyl)vinyl]quinolin-8-ol (5) was hydrolysed in methanol with $\mathrm{K}_{2} \mathrm{CO}_{3}$, then precipitated by concentrated $\mathrm{HCl}$ and crystallized from ethanol, see Scheme 2 .<smiles></smiles>

Scheme 2. Synthesis of compound 3-5. Reagents and conditions: (a) $\mathrm{Ac}_{2} \mathrm{O}, 80 \% \mathrm{AcOH}, 18 \mathrm{~h}$ at $130{ }^{\circ} \mathrm{C}$, and $\mathrm{N}_{2}$ atmosphere; (b) $\mathrm{MeOH}, \mathrm{K}_{2} \mathrm{CO}_{3}$, and $\mathrm{HCl}$.

After synthesis of compounds 3-5, their potential antibacterial activities were evaluated. While compound $\mathbf{5}$ showed moderate antibacterial activity, compounds 3 and 4 were inactive. It is interesting to note that the only structural difference between compound 5 and compounds 3 and 4 is the replacement of the $\mathrm{OH}$ group by $\mathrm{OAc}$ and $\mathrm{OCH}_{3}$, respectively. These results are in accord with those obtained for compounds $\mathbf{1}$ and $\mathbf{2}$, since the ethylation of the $\mathrm{OH}$ group of $\mathbf{1}$ produced significant loss of antibacterial activity. From these results, it appears that the presence of a proton donor group in the ring A of these compounds could play an important role in the antibacterial effect, e.g., compare Gonec et al. [24] with Kos et al. [25,26]. In order to understand better this behaviour, a conformational and electronic study was performed for these compounds with the aim to determine their stereo-electronic characteristics. Details about the type of molecular calculations and the methodology used are explained in the Section 3.4. In addition, details about the conformational analysis of the compounds are also given in the same section. Knowledge of the stereo-electronic attributes and properties of these compounds will contribute significantly to the elucidation of the structural requirements to produce antibacterial activity. Molecular electrostatic potentials (MEP) are of particular value, because they allow the visualization and assessment of the capacity of a molecule to interact electrostatically with a putative-binding site [27-29]. Thus, once the conformational behaviours of compounds reported here had been analysed, an electronic study of their respective preferred conformations by using Electrostatic Potentials Maps (EPMs) was performed. Figure 3 gives the Molecular Electrostatic Potentials (MEP) obtained for compounds 1 and $\mathbf{3}$. The MEP obtained for compound $\mathbf{1}$ (Figure 3a) exhibit three characteristic regions: a clear minimum value (deep red zone with $\mathrm{V}(\mathrm{r}) \mathrm{min} \approx-0.1559$ 
$\mathrm{el} / \mathrm{au} 3$ ) in the vicinity of the $\mathrm{OH}$ group of the ring $\mathrm{A}$, a positive region (deep blue zone with $\mathrm{V}(\mathrm{r}) \mathrm{max}$ $\approx 0.20 \mathrm{el} / \mathrm{au} 3$ ) located in the linker chain, and an extended hydrophobic zone (deep and light green zone with an almost neutral potential $\mathrm{V}(\mathrm{r}) \mathrm{med} \approx-0.0011 \mathrm{el} / \mathrm{au} 3)$ in the zone near to the ring $\mathrm{B}$.

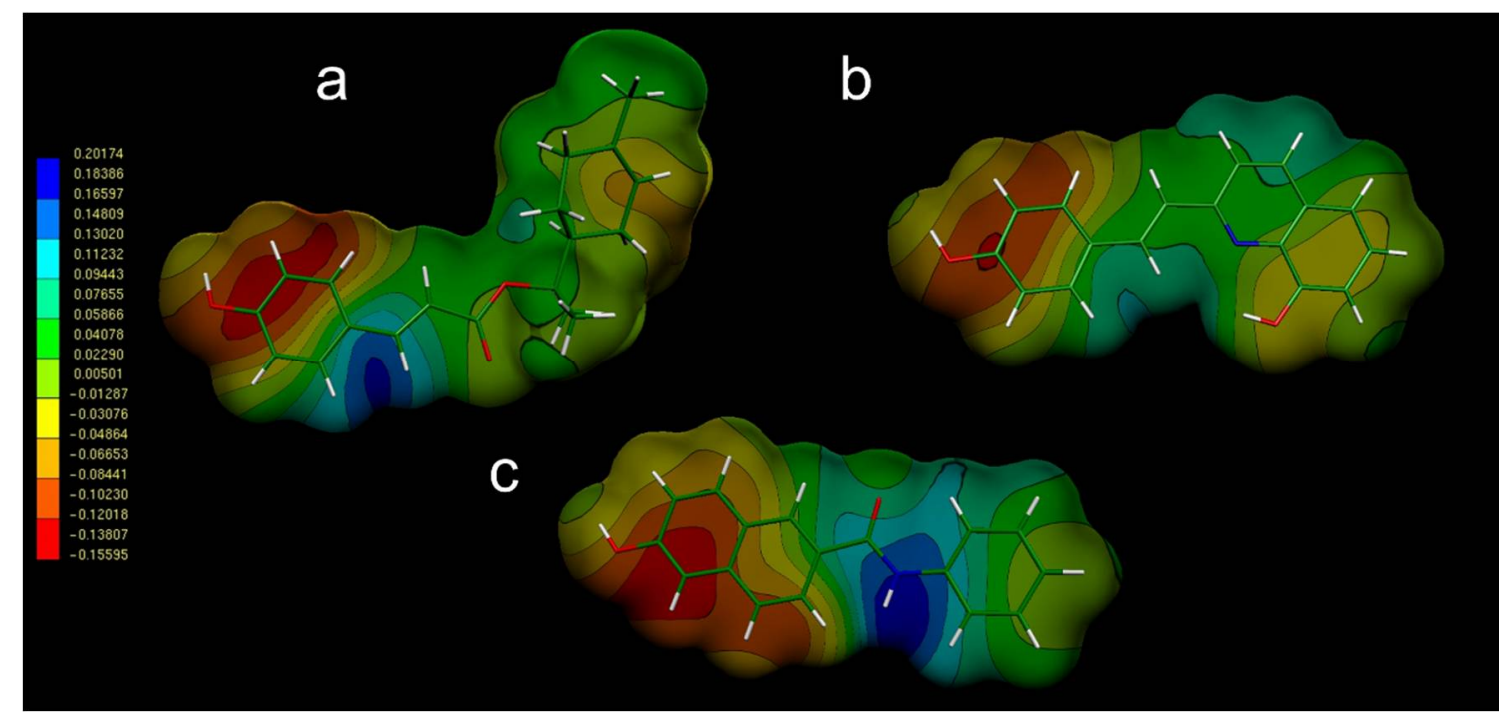

Figure 3. Electrostatic potential-encoded electron density surfaces of core structures of compounds 1 (a), 3 (b), and 6 (c). The colouring represents electrostatic potential, with red indicating the strongest attraction to a positive point charge and blue indicating the strongest repulsion. The electrostatic potential is the energy of interaction of the positive point charge with the nuclei and electrons of a molecule. It provides a representative measure of overall molecular charge distribution.

It is interesting to note that the MEP of compound $\mathbf{3}$ (Figure 3b) is similar to that obtained for $\mathbf{1}$. However, for compound 3 , both the most electronegative zone (zone with red and orange tones) and the electropositive part of the molecule (area with bluish tonalities) are significantly more tenuous with values of $\mathrm{V}(\mathrm{r}) \mathrm{min} \approx-0.120 \mathrm{el} / \mathrm{au} 3$ and $\mathrm{V}(\mathrm{r}) \max \approx 0.110 \mathrm{el} / \mathrm{au} 3$, respectively. These results are in agreement with the experimental data, considering that compound 3 displayed lower antibacterial activity than compound $\mathbf{1}$.

A series of carboxanilides with antimycobacterial properties, including 6-hydroxy-N-phenylnaphthalene-2-carboxamide (6) and 6-hydroxy- $N$-(3-trifluoromethylphenyl) naphthalene-2-carboxamide (7) (see Figure 1), was reported recently [25]. They were prepared according to Scheme 3 by modified microwave-assisted synthesis in one step with excellent yields. At first, the carboxyl group was activated with phosphorus trichloride. The final amide was immediately formed by aminolysis of acyl chloride by a ring-substituted aniline in dry chlorobenzene. All the crude target compounds were recrystallized from ethanol.<smiles>[R]c1cccc(NC(=O)c2ccc3cc(O)ccc3c2)c1</smiles>

Scheme 3. Synthesis of ring-substituted 6-hydroxynaphthalene-2-carboxanilides 6 and 7. Reagents and conditions: (a) $\mathrm{PCl}_{3}$, chlorobenzene, and microwave irradiation (MW) [25].

It should be noted that these compounds are naphthalene analogues (carbon isosteres) of the quinoline scaffold, i.e., they also possess fused rings in their structure (rings A and B), which gives a 
certain structural similarity to the first portion of compound 1. Next, a conformational and electronic study of compounds 6 and 7 was performed, and the results were compared with those obtained for the rest of compounds studied here. Figure $3 \mathrm{c}$ indicates that compound $\mathbf{6}$ displays MEP that are very similar to those obtained for compound $\mathbf{1}$ (compare Figure 3a,c). In this case, the values obtained for $\mathrm{V}(\mathrm{r}) \mathrm{max}$ and $\mathrm{V}(\mathrm{r}) \mathrm{min}$ are very similar to those observed in compound 1. A very similar result was obtained for compound 7. Based on these results, it was decided to test these compounds as potential antibacterial agents. Compounds 6 and 7, especially compound 7, showed significant antibacterial effects against the different strains studied here (Table 4). These experimental results fully agree with the molecular calculations and give additional support to the proposed pharmacophoric pattern. Once again, the presence of a proton donor group at ring A appears to be an essential structural requirement for antibacterial effect.

\section{Materials and Methods}

\subsection{Extractions and Isolation}

\subsubsection{General Methods}

${ }^{1} \mathrm{H}$ and ${ }^{13} \mathrm{C}-\mathrm{NMR}$ spectra were recorded on a High Resolution Spectrometer Advance 400 (working frequency $400 \mathrm{MHz}$ and $100 \mathrm{MHz}$, respectively) at ambient temperature in $\mathrm{CDC}_{13}$ (Aldrich, St. Louis, MO, USA). Carbon spectra assignments are supported by DEPT-135 spectra, ${ }^{13} \mathrm{C}-{ }^{1} \mathrm{H}$ (HMQC) and ${ }^{13} \mathrm{C}-{ }^{1} \mathrm{H}(\mathrm{HMBC})$, and NOESY correlations. High-resolution mass spectrums were measured on Bruker Micro TOF Q II equipment (Bruker, Karlsruhe, Germany), operated with an ESI source in the positive mode. Optical rotations were measured with a Jasco polarimeter DIP-1000 P-1010 34 (Jasco, Easton, MD, USA). The CD (Circular Dichroism) and UV-VIS spectra of methanol solutions of 1 and 2 were recorded simultaneously using a Jasco J-810 spectropolarimeter, model J-810 $150 \mathrm{~S}$ and a $100 \mathrm{~lm}$ quartz cuvette with resolution $1 \mathrm{~nm}$, time constant $1 \mathrm{~s}$, scan speed $100 \mathrm{~nm} / \mathrm{min}$, and 3 accumulations, employing standard sensitivity and a measurement range of 700-190 nm.

\subsubsection{Plant Material}

The aerial parts (leaves, flowers, and fruits) of A. emarginata were collected in San Cosme, province of Corrientes (Argentina) at 27.36667 lat. S; 58.51667 long. W, in the summer of 2013 and were authenticated by Dra. Elisa Petenatti and L.A. Del Vitto. A voucher specimen (L.A. Del Vitto \& E.M. Petenatti \# 9490) has been deposited at the Herbarium, National University of San Luis, Argentina.

\subsubsection{Preparation of Extracts}

Finely ground $A$. emarginata fruits $(100 \mathrm{~g})$ were extracted at room temperature using methanol $\mathrm{MeOH}(200 \mathrm{~mL} \times 3$-fold $\times 96 \mathrm{~h}$ each $)$, filtered and concentrated under reduced pressure to afford the corresponding crude global methanolic extract (MeOHGFE; $17.7 \mathrm{~g}$, yield 17.7\% $w / w$ ). Dried and finely ground $A$. emarginata flowers $(100 \mathrm{~g})$ were successively extracted at room temperature (200 $\mathrm{mL} \times 3$-fold $\times 96 \mathrm{~h}$, each $3 \times 24 \mathrm{~h}$ ) with hexane $(\mathrm{H})$, dichloromethane $(\mathrm{DCM})$, ethyl acetate $($ EtOAc), and methanol $(\mathrm{MeOH})$. Then, solvents were evaporated under vacuum to give flower extracts $\mathrm{HFIE}$, DCMFlE, EtOAcFlE, and MeOHFlE with yields $(w / w)$ of $4.3 \%, 1.9 \%, 0.66 \%$, and 5.9\%, respectively. Finely ground dried $A$. emarginata stem bark $(100 \mathrm{~g})$ was successively extracted at room temperature $(200 \mathrm{~mL} \times 3$-fold $\times 96 \mathrm{~h}$, each $3 \times 24 \mathrm{~h})$ with $\mathrm{H}, \mathrm{DCM}, \mathrm{EtOAc}$, and $\mathrm{MeOH}$. The solvents were evaporated under vacuum to afford bark extracts HBE, DCMBE, EtOAcBE, and MeOHBE with yields $(w / w)$ of $0.92 \%, 0.27 \%, 0.34 \%$, and $4.23 \%$, respectively. Finely ground dried A. emarginata leaves (100 g) were successively extracted at room temperature $(200 \mathrm{~mL} \times 3$-fold $\times 96 \mathrm{~h}$, each $3 \times 24 \mathrm{~h})$ with $\mathrm{H}$, DCM, EtOAc, and $\mathrm{MeOH}$. Then, solvents were evaporated under vacuum to produce leaf extracts HLE, DCMLE, EtOAcLE, and MeOHLE, affording $0.63 \%, 1.54 \%, 0.75 \%$, and $1.02 \%$ yield ( $w / w)$, respectively. 


\subsubsection{Bioassay-Guided Fractionation of Annona emarginata Fruit Extracts (MeOHGFE)}

MeOHGFE (11 g) was applied onto a column (column length $70 \mathrm{~cm}$, i.d. $5 \mathrm{~cm}$ ) containing silica gel (0.063-0.2 mesh, Merck 60, Merck, Darmstadt, Germany) and eluted with H, DCM, and EtOAc gradients (100\% $\mathrm{H}$ to $100 \%$ EtOAc). Six fractions of $1 \mathrm{~L}$ each were obtained, which concentrated under reduced pressure to afford $\mathrm{F}_{1}$ (200 mg; $\left.\mathrm{H} 100 \%\right), \mathrm{F}_{2}(115 \mathrm{mg} ; 50: 50 \% \mathrm{H} / \mathrm{DCM}), \mathrm{F}_{3}(1200 \mathrm{mg}$; 90:10\% DCM/EtOAc), F 4 (187.7 mg 80:20\% DCM/EtOAc), F5 (155 mg; 70:30\% DCM/EtOAc), and $\mathrm{F}_{6}\left(137 \mathrm{mg}\right.$; EtOAc 100\%) fractions. Fractions $\mathrm{F}_{1}-\mathrm{F}_{6}$ were tested for antimicrobial activity. Fraction $\mathrm{F}_{3}(1100 \mathrm{mg}$ ) permeated through Sephadex LH-20 (column length $23 \mathrm{~cm}$, i.d. $4 \mathrm{~cm}$; petroleum ether (PE)/MeOH/DCM 2:1:1). Some 21 fractions of $15 \mathrm{~mL}$ each were obtained. After TLC comparison (silica gel, PE/EtOAc 8:2) as the mobile phase, detection under UV light and spraying with $p$-anisaldehyde sulfuric acid, the fractions with similar TLC patterns were combined as follows: I (477 mg), II (142 mg), III (98 mg), IV (295 mg), and V (84 mg).

3.1.5. Isolation and Characterization of (R)-2-(4-Methylcyclohex-3-en-1-yl)propan-2-yl (E)-3-(4-hydroxyphenyl)acrylate (1)

Separation of the fraction IV (295 mg) using column chromatography on silica gel (column length $40 \mathrm{~cm}$, internal diameter $2 \mathrm{~cm}$; $50 \mathrm{~g}$ silica gel 0.063-0.2 mesh, Merck 60); (100\% H to 100\% EtOAc) provided $200 \mathrm{mg}$ of pure compound 1: oil; $[\alpha]_{\mathrm{D}}^{23}+29\left(\mathrm{c}=0.17 \mathrm{~g} / 100 \mathrm{~mL}, \mathrm{CHCl}_{3}\right),{ }^{1} \mathrm{H}-\mathrm{NMR}(400 \mathrm{MHz}$, $\left.\mathrm{CDCl}_{3}\right) \delta 1.50\left(\mathrm{~s}, 3 \mathrm{H}, \mathrm{H}-9^{\prime}\right), 1.53\left(\mathrm{~s}, 3 \mathrm{H}, \mathrm{H} 10^{\prime}\right), 1.67\left(\mathrm{~s}, 3 \mathrm{H}, \mathrm{H}-7^{\prime}\right), 1.85-1.35\left(\mathrm{~m}, 2 \mathrm{H}, \mathrm{H}-3^{\prime}\right), 2.12(\mathrm{~m}, 1 \mathrm{H}$, H-4' ${ }^{\prime}$, 2.16-1.86 (m, 4H, H-2' , H-5'), 5.39 (s, 1H, H-6 $\left.{ }^{\prime}\right), 6.22$ (d, J = 16 Hz, 1H, H-8), 6.85 (d, J = 8Hz, 2H, H-3 and H-5), 7.38 (d, $J=8 \mathrm{~Hz}, 2 \mathrm{H}, \mathrm{H}-2$ and H-6), $7.51(\mathrm{~d}, J=16 \mathrm{~Hz}, 1 \mathrm{H}, \mathrm{H}-7) ;{ }^{13} \mathrm{C}-\mathrm{NMR}(100 \mathrm{MHz}$, $\left.\mathrm{CDCl}_{3}\right) \delta 23.3 \mathrm{CH}_{3}, \delta 23.4 \mathrm{CH}_{3}, 23.5 \mathrm{CH}_{3}, 24.0 \mathrm{CH}_{2}, 26.5 \mathrm{CH}_{2}, 30.9 \mathrm{CH}_{2}, 42.8 \mathrm{CH}\left(\mathrm{C}-4^{\prime}\right), 85.2 \mathrm{C}\left(\mathrm{C}-8^{\prime}\right)$, $115.9 \mathrm{CH} \times 2(\mathrm{C}-3$ and $\mathrm{C}-5), 117.2 \mathrm{CH}(\mathrm{C}-8), 120.3 \mathrm{CH}\left(\mathrm{C}-6^{\prime}\right), 127.0(\mathrm{C}-1), 129.9 \mathrm{CH} \times 2(\mathrm{C}-2$ and C-6), $134.0\left(\mathrm{C}-1^{\prime}\right), 143.8(\mathrm{C}-7), 158.4(\mathrm{C}-4), 167.8 \mathrm{C}(\mathrm{C}=\mathrm{O})$, HR-EIMS 323.1618, (calcd for $\mathrm{C}_{19} \mathrm{H}_{24} \mathrm{O}_{3}(\mathrm{M}+\mathrm{Na})$ 323.1618). (See spectra in Supplementary Material).

\subsection{Synthesis}

\subsubsection{General Methods}

All of the reagents were purchased from Aldrich. Kieselgel 60, 0.040-0.063 mm (Merck, Darmstadt, Germany) was used for the column chromatography. TLC experiments were performed on alumina-backed silica gel $40 \mathrm{~F}_{254}$ plates (Merck, Darmstadt, Germany). The plates were illuminated under UV (254 nm) and evaluated in iodine vapour. The melting points were determined on an Optimelt MPA-100 apparatus (SRS, Stanford, CA, USA). The purity of the final compounds was checked using HPLC. Detection wavelengths of 210 and $250 \mathrm{~nm}$ were chosen for detection. The purity of individual compounds was determined from the area peaks in the chromatogram of the sample solution in order to ensure $>95 \%$ purity. All ${ }^{1} \mathrm{H}-\mathrm{NMR}$ spectra were recorded on a Bruker AM-400 (400 MHz for ${ }^{1} \mathrm{H}$ and 101/126 MHz for ${ }^{13} \mathrm{C}$ ), BrukerBioSpin Corp., Rheinstetten, Germany. Chemical shifts are reported in ppm $(\delta)$ against the internal standard, $\mathrm{Si}\left(\mathrm{CH}_{3}\right)_{4}$. Easily exchangeable signals were omitted when they were diffused. Signals are designated as follows: s, singlet; d, doublet; dd, doublet of doublets; m, multiplet. The high-resolution mass spectra of compounds 3-5 were measured using a high-performance liquid chromatograph Dionex UltiMate®3000 (Thermo Scientific, Waltham, MA, USA) coupled with a LTQ Orbitrap XLTM Hybrid Ion Trap-Orbitrap Fourier Transform Mass Spectrometer (Thermo Scientific) with injection into HESI II in the positive mode.

\subsubsection{Synthesis of (R)-2-(4-Methylcyclohex-3-en-1-yl)propan-2-yl (E)-3-(4-ethoxyphenyl)acrylate (2)}

In a Schlenk tube equipped with a magnetic stirrer, $t$-BuOK $(0.118 \mathrm{mmol})$ was added to $2 \mathrm{~mL}$ of degassed DMSO under nitrogen atmosphere. After $10 \mathrm{~min}$, when no more solid was present, compound $1(0.098 \mathrm{mmol})$ was added. The reaction mixture was stirred for $30 \mathrm{~min}$ until the formation of the corresponding ions. The reaction was then quenched by adding excess ethyl iodide (0.196 mmol) 
to obtain compound 2 . The solution was extracted with ethyl acetate and water. The organic extract was analysed by GC-MS. The reaction was then quenched by adding excess ethyl iodide (0.196 mmol) to obtain a brown oil that was purified by column chromatography on silica gel (column length 40 $\mathrm{cm}$, internal diameter $2 \mathrm{~cm} ; 50 \mathrm{~g}$ silica gel (0.063-0.2 mesh, Merck 60) using a solvent gradient (100\% PE to $100 \%$ EtOAc) to afford $110 \mathrm{mg}$ of pure compound 2: oil (yield 95\%); $[\alpha]_{\mathrm{D}}^{23}+23(\mathrm{c}=0.11 \mathrm{~g} / 100$ $\left.\mathrm{mL}, \mathrm{CHCl}_{3}\right),{ }^{1} \mathrm{H}-\mathrm{NMR}\left(400 \mathrm{MHz}, \mathrm{CDCl}_{3}\right) \delta 1,42\left(\mathrm{t}, 3 \mathrm{H}, \mathrm{CH}_{3}\right.$ ethyl), $1.50\left(\mathrm{~s}, 3 \mathrm{H}, \mathrm{H}-9^{\prime}\right), 1.53\left(\mathrm{~s}, 3 \mathrm{H}, \mathrm{H} 10^{\prime}\right)$, 1.65 (s, 3H, H-7'), 1.85-1.35 (m, 2H, H-3'), 2.12 (m, 1H, H-4') 2.16-1.86 (m, 4H, H-2' , H-5'), 4.05 (q, $2 \mathrm{H}$, $\mathrm{CH}_{2}$ ethyl), $5.39\left(\mathrm{~s}, 1 \mathrm{H}, \mathrm{H}-6^{\prime}\right), 6.23(\mathrm{~d}, J=16 \mathrm{~Hz}, 1 \mathrm{H}, \mathrm{H}-8), 6.87(\mathrm{~d}, J=8 \mathrm{~Hz}, 2 \mathrm{H}, \mathrm{H}-3, \mathrm{H}-5), 7.44(\mathrm{~d} J=8$ $\mathrm{Hz}, 2 \mathrm{H}, \mathrm{H}-2, \mathrm{H}-6), 7.52$ (d, $J=16 \mathrm{~Hz}, 1 \mathrm{H}, \mathrm{H}-7) ;{ }^{13} \mathrm{C}-\mathrm{NMR}\left(100 \mathrm{MHz}, \mathrm{CDCl}_{3}\right) \delta 14.7 \mathrm{CH}_{3}$ (ethyl) 23.3 $\mathrm{CH}_{3}, 23.4 \mathrm{CH}_{3}, 23.5 \mathrm{CH}_{3}, 24.0 \mathrm{CH}_{2}, 26.5 \mathrm{CH}_{2}, 30.9 \mathrm{CH}_{2}, 42.7 \mathrm{CH}\left(\mathrm{C}-4^{\prime}\right), 63.5\left(\mathrm{~s}, 2 \mathrm{H}, \mathrm{CH}_{2}\right.$ ethyl), 84.9 C $\left(\mathrm{C}-8^{\prime}\right), 114,7 \mathrm{CH}(\mathrm{C}-3, \mathrm{C}-5), 117.6 \mathrm{CH}(\mathrm{C}-8), 120.4 \mathrm{CH}\left(\mathrm{C}-6^{\prime}\right), 127.2(\mathrm{C}-1), 129.6 \mathrm{CH}(\mathrm{C}-2$ and C-6), 134.0 $\left(\mathrm{C}-1^{\prime}\right), 143.3(\mathrm{C}-7), 160.0 \mathrm{CH}(\mathrm{C}-4), 168.9 \mathrm{C}(\mathrm{C}=\mathrm{O})$, HREIMS 351.1935, (calcd for $\mathrm{C}_{21} \mathrm{H}_{28} \mathrm{O}_{3}(\mathrm{M}+\mathrm{Na})$ 351.1931). (See spectra in Supplementary Material).

\subsubsection{General Synthesis of Styrylquinoline Derivatives 3-5}

The appropriate quinoline derivative $(2.5 \mathrm{mmol})$ in acetic anhydride with $80 \%$ acetic acid was thoroughly mixed with one equivalent aldehyde and heated in an inert gas atmosphere $\left(\mathrm{N}_{2}\right)$ at $130{ }^{\circ} \mathrm{C}$ for $18 \mathrm{~h}$. Then, the mixture was evaporated to dryness, and a solid was recrystallized from ethanol. The appropriate styrylquinoline derivative $(2.5 \mathrm{mmol})$ in methanol was thoroughly mixed with 2.5 equivalent $\mathrm{K}_{2} \mathrm{CO}_{3}$ at room temperature for $2 \mathrm{~h}$. Then, concentrated $\mathrm{HCl}$ was added, and the resulting precipitate was filtered and washed with $\mathrm{H}_{2} \mathrm{O}$. The crude product was crystallized from ethanol.

2-[2-(4-Methoxyphenyl)vinyl]quinolin-8-yl acetate (3): yield 20\%, light brown solid, m.p. $97-100{ }^{\circ} \mathrm{C}$; HPLC purity 95.82\%; ${ }^{1} \mathrm{H}-\mathrm{NMR}\left(400 \mathrm{MHz}, \mathrm{DMSO}-\delta_{6}\right) \delta 8.38(\mathrm{~d}, J=8.6 \mathrm{~Hz}, 1 \mathrm{H}), 7.90-7.82(\mathrm{~m}, 2 \mathrm{H}), 7.78$ $(\mathrm{d}, J=16.3 \mathrm{~Hz}, 1 \mathrm{H}), 7.70(\mathrm{~d}, J=8.5 \mathrm{~Hz}, 2 \mathrm{H}), 7.57-7.47(\mathrm{~m}, 2 \mathrm{H}), 7.30(\mathrm{~d}, J=16.3 \mathrm{~Hz}, 1 \mathrm{H}), 7.02(\mathrm{~d}, J=$ $8.5 \mathrm{~Hz}, 2 \mathrm{H}), 3.82(\mathrm{~s}, 3 \mathrm{H}), 2.50(\mathrm{~s}, 3 \mathrm{H}) ;{ }^{13} \mathrm{C}-\mathrm{NMR}\left(126 \mathrm{MHz}, \mathrm{DMSO}-\delta_{6}\right) \delta 172.49,160.23,154.26,153.29$, 138.60, 136.84, 134.57, 129.58, 129.39, 129.11, 127.97, 127.24, 126.14, 122.09, 121.25, 118.02, 114.87, 111.58, 55.69, 21.52. HR-MS: for $\mathrm{C}_{20} \mathrm{H}_{18} \mathrm{NO}_{3}[\mathrm{M}+\mathrm{H}]^{+}$calculated $320.1281 \mathrm{~m} / \mathrm{z}$, found $320.1284 \mathrm{~m} / \mathrm{z}$.

2-[2-(4-Acetoxyphenyl)vinyl]quinolin-8-yl acetate (4): yield 67\%, yellow solid, m.p. 157-159 ${ }^{\circ} \mathrm{C}$; HPLC purity $95.83 \% ;{ }^{1} \mathrm{H}-\mathrm{NMR}\left(400 \mathrm{MHz}, \mathrm{CDCl}_{3}\right) \delta 8.15(\mathrm{dd}, J=8.5,5.1 \mathrm{~Hz}, 1 \mathrm{H}), 7.73-7.60(\mathrm{~m}, 5 \mathrm{H}), 7.55-7.37$ $(\mathrm{m}, 3 \mathrm{H}), 7.19-7.12(\mathrm{~m}, 2 \mathrm{H}), 2.58(\mathrm{~s}, 3 \mathrm{H}), 2.35$ (s, 3H); ${ }^{13} \mathrm{C}-\mathrm{NMR}\left(101 \mathrm{MHz}, \mathrm{CDCl}_{3}\right) \delta 169.84,169.33$, $155.65,150.91,147.38,140.94,136.41,134.25,133.71,131.21,129.10,128.60,128.32,125.75,125.54,121.95$, 121.68, 120.19, 21.17, 21.03. HR-MS: for $\mathrm{C}_{21} \mathrm{H}_{18} \mathrm{NO}_{4}[\mathrm{M}+\mathrm{H}]^{+}$calculated $348.1230 \mathrm{~m} / z$, found 348.1239 $m / z$.

2-[2-(4-Hydroxyphenyl)vinyl]quinolin-8-ol (5): yield 63\%, orange solid, m.p. $156-157^{\circ} \mathrm{C}$; HPLC purity 98.38\%; ${ }^{1} \mathrm{H}-\mathrm{NMR}\left(400 \mathrm{MHz}, \mathrm{DMSO}-\delta_{6}\right) \delta 11.81(\mathrm{~s}, 1 \mathrm{H}), 10.38(\mathrm{~s}, 1 \mathrm{H}), 8.84(\mathrm{~d}, J=8.9 \mathrm{~Hz}, 1 \mathrm{H}), 8.42(\mathrm{~d}, J=$ $8.9 \mathrm{~Hz}, 1 \mathrm{H}), 8.22(\mathrm{~d}, J=16.2 \mathrm{~Hz}, 1 \mathrm{H}), 7.79(\mathrm{~d}, J=16.3 \mathrm{~Hz}, 1 \mathrm{H}), 7.67-7.56(\mathrm{~m}, 4 \mathrm{H}), 7.47(\mathrm{dd}, J=6.1,2.6$ $\mathrm{Hz}, 1 \mathrm{H}), 6.95(\mathrm{~d}, J=8.6 \mathrm{~Hz}, 2 \mathrm{H}) ;{ }^{13} \mathrm{C}-\mathrm{NMR}\left(126 \mathrm{MHz}, \mathrm{DMSO}-\delta_{6}\right) \delta 161.19,153.30,148.85,144.14,143.99$, $143.72,130.85,129.57,128.20,126.55,119.16,118.74,116.83,116.50$. HR-MS: for $\mathrm{C}_{17} \mathrm{H}_{13} \mathrm{NO}_{2}[\mathrm{M}+\mathrm{H}]^{+}$ calculated $264.1019 \mathrm{~m} / \mathrm{z}$, found $264.1028 \mathrm{~m} / \mathrm{z}$.

6-Hydroxy-N-phenylnaphthalene-2-carboxamide (6) and 6-hydroxy- $N$-(3-trifluoromethylphenyl)naphthalene-2-carboxamide (7) were synthesized and characterized recently [25].

\subsection{Antibacterial Activity}

For the antibacterial evaluation, methicillin-sensitive Staphylococcus aureus ATCC 25923, methicillin-resistant S. aureus ATCC 43300, Escherichia coli ATCC 25922, and clinical isolates from human patients-coagulase negative Staphylococcus aureus 502, Streptococcus pyogenes, Streptococcus agalactiae, Escherichia coli LM2, Salmonella sp. and Klebsiella pneumoniae-provided by Laboratorio de Microbiologia, Hospital Marcial Quiroga, San Juan, Argentina, were used. 
Minimal inhibitory concentration (MIC) values were determined using the broth microdilution method according to the protocols of the Clinical and Laboratory Standards Institute [30]. The assay was executed in Mueller-Hinton broth (MHB), using strains $24 \mathrm{~h}$ old. The inoculum employed was $1-5 \times 10^{5} \mathrm{CFU} / \mathrm{mL}$. Stock solutions of extracts in DMSO $(50 \mathrm{mg} / \mathrm{mL})$ were diluted to give serial 2-fold dilutions that were added to each medium to obtain final concentrations ranging from 1000 to $1 \mu \mathrm{g} / \mathrm{mL}$. Stock solutions of compounds in DMSO $(5 \mathrm{mg} / \mathrm{mL})$ were diluted to give serial 2 -fold dilutions that were added to each medium to obtain final concentrations ranging from 50 to $1 \mu \mathrm{g} / \mathrm{mL}$. The final concentration of DMSO in the assay did not exceed 1\%. Cefotaxime Argentia ${ }^{\circledR}$ (Bristol-Myers Squibb, Buenos Aires, Argentina) was included in the assays as a positive control, while MHB and DMSO (1\%) were used as negative controls. The plates were incubated for $24 \mathrm{~h}$ at $37^{\circ} \mathrm{C}$. Activity was evaluated at $620 \mathrm{~nm}$ using a Multiskan ${ }^{\mathrm{TM}}$ FC Microplate Photometer (Thermo Fisher Scientific, Vantaa, Finland). The MIC values were defined as the lowest extract concentrations showing no bacterial growth after the incubation time. Tests were done in triplicate.

\subsection{Conformational and Electronic Study}

All calculations were carried out using the Gaussian 09 program (Gaussian, Wallingford, CT, USA) [31]. The search for low-energy conformations on the potential energy surface for compounds $1,3,6$, and 7 was carried out by using combined ab initio (RHF/3-21G) and density functional theory (DFT) (B3LYP /6-31G(d)) calculations. Final DFT geometries were obtained from the geometry optimisation jobs. Minima were characterized through harmonic frequency analysis calculated at DFT level. Correlations effects were included using DFT and the functional of Lee [32] as proposed and parameterized by Becke [33,34] (RB3LYP) and 6-31G (d) basis set. Compound $\mathbf{1}$ looks like a relatively simple conformational problem, in which three torsional angles $(\phi 1, \phi 2$, and $\phi 3$, Figure 1) are main rotations in this molecule. Our calculations predict that the torsional angle $\phi 1$ possesses only two possible quasi-planar conformations: one of them near to $0^{\circ}$, and the opposite position giving values near to $180^{\circ}$. The energy barrier obtained for this rotation is more than $10 \mathrm{Kcal} / \mathrm{mol}$, suggesting a significantly restricted torsional angle (see Figure S1 in Supplementary Material). It should be noted that the cis form possesses about $1 \mathrm{Kcal} / \mathrm{mol}$ above the trans form; therefore, the conformational analysis of compound 1 considering $\phi 1$ near to $180^{\circ}$ was performed. The orientations of the ring $\mathrm{B}$ are mainly described by the dihedral angles $\phi 2$ and $\phi 3$, and probably the most comprehensive computational method to evaluate how the local energy minima and the transition states are linked together requires an exploration of the complete potential energy surface (PES) generated by $\phi 2 \mathrm{vs}$. $\phi 3$. This PES was calculated using a $12 \times 12$ grid generated by rotating through $\phi 2$ and $\phi 3$ in $30^{\circ}$ increments from -180 to $180^{\circ}$. At each point, a complete geometry optimization was performed with $\phi 2$ and $\phi 3$ frozen at their respective grid values. The graphical presentation of the PES was generated using the program AXUN 5.0 (MathSoft, Cambridge, MA, USA), plotting the total energy values as a dependent variable generated by double scans over independent variables $\phi 2$ and $\phi 3$. The optimum coordinates of $\phi 2$ and $\phi 3$ for all possible minima were then visually estimated from the level contours diagrams (Figure S2 in Supplementary Material). Five different conformations (conformations 1-5) were obtained for $\mathbf{1}$; such low-energy conformers might be well appreciated in this surface. The global minimum (conformer 1) corresponds to a partially extended form (see Table S1 in Supplementary Material). On the other hand, the conformational analysis suggests planar forms as energetically preferred structures for compounds 3, 6, and 7 . This is an expected result, considering the structural characteristics of their connecting chains. In compound 3, it is a highly delocalized system, while in compounds 6 and 7 , it is a peptide bond. The electronic study of compounds 1, 3, 6, and 7 was carried out using molecular electrostatic potentials (MEP) [27]. MEP have been shown to provide reliable information both on the interaction sites of the molecules with point charges and on the comparative reactivities of such sites [28,29]. These MEP were calculated using B3LYP/6-311G $(d, p)$ wave functions from the MOLEKEL 4.0. program (CSCS, Manno, Switzerland) [35]. 


\section{Conclusions}

Strong antibacterial activities found for some of the extracts studied here fully justify the use of infusions and decoctions of Annona emarginata (Schltdl.) H. Rainer in folk medicine for the treatment of some infections. First, it is interesting to remark that the less polar flower extracts (hexane, dichloromethane) showed very strong antibacterial activity against methicillin-sensitive S. aureus ATCC 25923 and methicillin-sensitive S. aureus ATCC 43300. Additionally, the hexane extract showed activity against $K$. pneumoniae, while the methanol extract from the fruits was also active against the three strains mentioned above. Such activity might be explained at least in part by the content of the new main compound (R)-2-(4-methylcyclohex-3-en-1-yl)propan-2-yl (E)-3-(4-hydroxyphenyl)acrylate (1). This compound showed strong antimicrobial activity against all Gram (+) species tested. The demand for new antibacterial agents and the new trend towards the use of characterized natural extracts or compounds isolated as medicines instead of pure drugs might open an alternative way for the development of new antibacterial agents, trying to avoid the serious problem of resistance to the antibiotics in use today. On the other hand, the molecular calculations allowed for the establishment of structure-activity relationships between the antibacterial compounds reported here, which gives important information about a possible pharmacophoric pattern of these compounds. This information may be of great interest for the search and procurement of new structurally related antibacterial agents.

Supplementary Materials: The Supplementary materials are available online.

Author Contributions: Ricardo D. Enriz, Josef Jampilek, and Alejandro Tapia conceived and designed the experiments. Juan G. Dolab, Beatriz Lima, Natividad H. Cano, Gabriela Feresin, and Alejandro Tapia performed and analyzed the experiments, isolation, synthesis, the spectroscopic data of compounds $\mathbf{1}$ and $\mathbf{2}$, and the antibacterial activity. Francisco Garibotto and Monica Olivella performed the molecular modelling. Ewelina Spaczynska and Robert Musiol performed synthesis and characterization of compounds 3-5. Jiri Kos and Josef Jampilek performed synthesis and characterization of compounds $\mathbf{6}$ and 7. Elisa Petenatti identified the plant. All authors wrote, read, and approved the final manuscript.

Acknowledgments: This research was partially supported by grants from Universidad Nacional de San Luis and PIP 444-CONICET. J.D. thanks a fellowship from CONICET. E.S. and R.M. appreciate National Science Centre grant No 2013/09/B/NZ7/00423. J.K. and J.J. were supported by the grant of the Faculty of Pharmacy of Comenius University in Bratislava No. FaF UK/37/2018 and by SANOFI-AVENTIS Pharma Slovakia, s.r.o. The authors thank Luis A. Del Vitto (UNSL) for his help in the botanical classification and Marcos Maiocchi (UNNE) for the help in the collection of the plant material. B.L., G.E.F. and A.T. thank CICITCA-UNSJ.

Conflicts of Interest: The authors declare no conflict of interest.

\section{References}

1. Moreira, I.C.; Lago, J.H.G.; Young, M.C.M.; Roque, N.F. Antifungal aromadendrane sesquiterpenoids from the leaves of Xylopia brasiliensis. J. Braz. Chem. Soc. 2003, 14, 828-831. [CrossRef]

2. Takahashi, J.A.; Pereira, C.R.; Pimenta, L.P.; Boaventura, M.A.; Silva, L.G. Antibacterial activity of eight Brazilian Annonaceae plants. Nat. Prod. Res. 2006, 20, 21-26. [CrossRef] [PubMed]

3. Santos Pimenta, L.P.; Pinto, G.B.; Takahashi, J.A.; Silva, L.G.F.; Boaventura, M.A.D. Biological screening of Annonaceous Brazilian Medicinal Plants using Artemia salina (Brine Shrimp Test). Phytomedicine 2003, 10, 209-212. [CrossRef] [PubMed]

4. Novaes, P.; Bezerra Torres, P.; Alves, D.Y.; dos Santos, C. Biological activities of Annonaceae species extracts from Cerrado. Braz. J. Bot. 2016, 39, 131-137. [CrossRef]

5. Frausin, G.; Lima, R.B.S.; Hidalgo, A.F.; Maas, P.; Pohlit, A.M. Plants of the Annonaceae traditionally used as antimalarials: A review. Rev. Bras. Frutic. 2014, 36, 315-337. [CrossRef]

6. Waechter, A.I.; Cave, A.; Hocquemiller, R.; Bories, C.; Munoz, V.; Fournet, A. Antiprotozoal activity of aporphine alkaloids isolated from Unonopsis buchtienii (Annonaceae). Phytotherapy Res. 1999, 13, 175-177. [CrossRef]

7. Chen, Y.; Xu, S.S.; Chen, J.W.; Wang, Y.; Xu, H.Q.; Fan, N.B.; Li, X. Anti-tumor activity of Annona squamosa seeds extract containing annonaceous acetogen in compounds. J. Ethnopharmacol. 2012, 142, 462-466. [CrossRef] [PubMed] 
8. Monks, N.R.; Bordignon, S.A.L.; Ferraz, A.; Machado, K.R.; Faria, D.H.; Lopes, R.M.; Mondin, C.A.; Schwartsmann, G. Anti-tumour screening of Brazilian plants. Pharm. Biol. 2002, 40, 603-616. [CrossRef]

9. Barboza, G.E.; Cantero, J.J.; Nunez, C.; Pacciaroni, A.; Ariza Espinar, L. Medicinal plants: A general review and a phytochemical and ethnopharmacological screening of the native Argentine flora. Kurtziana 2009, 34, 7-365.

10. Martinez Crovetto, R. Plantas Utilizadas en Medicina en el NO de Corrientes; Ministry of Culture and Education, Miguel Lillo Foundation: Tucuman, Argentina, 1981.

11. Fevrier, A.; Ferreira, M.E.; Fournet, A.; Yaluff, G.; Inchausti, A.; Rojas de Arias, A.; Hocquemiller, R.; Waechter, A.I. Acetogenins and other compounds from Rollinia emarginata and their antiprotozoal activities. Planta Med. 1999, 65, 47-49. [CrossRef] [PubMed]

12. Colom, O.A.; Popich, S.; Bardon, A. Bioactive constituents from Rollinia emarginata (Annonaceae). Nat. Prod. Res. 2007, 21, 254-259. [CrossRef] [PubMed]

13. Roth, M.; Araya, J.J.; Timmermann, B.N.; Hagenbuch, B. Isolation of modulators of the liver-specific organic anion-transporting polypeptides (OATPs) 1B1 and 1B3 from Rollinia emarginata Schltdl. (Annonaceae). J. Pharmacol. Exp. Ther. 2011, 339, 624-632. [CrossRef] [PubMed]

14. Nieto, M. Alkaloids from Rollinia emarginata. J. Nat. Prod. 1986, 49, 717. [CrossRef] [PubMed]

15. Leboeuf, M.; Cave, A.; Bhaumik, P.K.; Mukherjee, B.; Mukherjee, R. The phytochemistry of the Annonaceae. Phytochem 1982, 21, 2783-2813. [CrossRef]

16. O'Neill, J. Tackling Drug-Resistant Infections Globally: Final Report and Recommendations; HM Government and the Wellcome Trust: London, UK, 2016.

17. Gagetti, P.; Corso, A. Actualización en Staphylococcus aureus resistente a meticilina de la comunidad. Bol. Assoc. Argent. Microbiol. 2011, 193, 7-8.

18. Faini, F.; Labbe, C.; Torres, R.; Rodilla, J.M.; Silva, L.; Delle Monache, F. New phenolic esters from the resinous exudate of Haplopappus taeda. Fitoterapia 2007, 78, 611-613. [CrossRef] [PubMed]

19. Feresin, G.E.; Tapia, A.; Gimenez, A.; Gutierrez Ravelo, A.; Zacchino, S.; Sortino, M.; Schmeda-Hirschman, G. Constituents of the Argentinean medicinal plant Baccharis grisebachii and their antimicrobial activity. J. Ethnopharmacol. 2003, 89, 73-80. [CrossRef]

20. Gianello, J.C.; Giordano, O.S. Constituents from Bacccharis grisebachii. An. Assoc. Quím. Argent. 1987, 75, 1-3.

21. Bisogno, F.; Mascoti, L.; Sanchez, C.; Garibotto, F.; Giannini, F.; Kurina, M.; Enriz, R.D. Structure-antifungal activity relationship of related cinnamic acid derivatives. J. Agric. Food Chem. 2007, 55, 10635-10640. [CrossRef] [PubMed]

22. Ioset, J.R.; Marston, A.; Gupta, M.P.; Hostettmann, K. Antifungal and larvicidal compounds from the root bark of Cordia alliodora. J. Nat. Prod. 2000, 63, 424-426. [CrossRef] [PubMed]

23. Kim, J.H.; Campbell, B.C.; Mahomey, N.E.; Chan, K.L.; Molyneux, R.J. Identification of phenolics for control of Aspergillus flavus using Saccharomyces cerevisiae in a model target-gene bioassay. J. Agric. Food Chem. 2004, 52, 7814-7821. [CrossRef] [PubMed]

24. Gonec, T.; Bobal, P.; Sujan, J.; Pesko, M.; Guo, J.; Kralova, K.; Pavlacka, L.; Vesely, L.; Kreckova, E.; Kos, J.; et al. Investigating the spectrum of biological activity of substituted quinoline-2-carboxamides and their isosteres. Molecules 2012, 17, 613-644. [CrossRef] [PubMed]

25. Kos, J.; Nevin, E.; Soral, M.; Kushkevych, I.; Gonec, T.; Bobal, P.; Kollar, P.; Coffey, A.; O’Mahony, J.; Liptaj, T.; et al. Synthesis and antimycobacterial properties of ring-substituted 6-hydroxynaphthalene-2-carboxanilides. Bioorg. Med. Chem. 2015, 23, 2035-2043. [CrossRef] [PubMed]

26. Kos, J.; Zadrazilova, I.; Nevin, E.; Soral, M.; Gonec, T.; Kollar, P.; Oravec, M.; Coffey, A.; O’Mahony, J.; Liptaj, T; et al. Ring-substituted 8-Hydroxyquinoline-2-carboxanilides as potential antimycobacterial agents. Bioorg. Med. Chem. 2015, 23, 4188-4196. [CrossRef] [PubMed]

27. Polilzer, P.; Truhlar, D.G. Chemical Applications of Atomic and Molecular Electrostatic Potentials; Plenum Publishing: New York, NY, USA, 1991.

28. Carrupt, P.A.; El Tayar, N.; Karlen, A.; Testa, B. Molecular electrostatic potentials for characterizing drug-biosystem interactions. Methods Enzymol. 1991, 202, 638-677.

29. Geerlings, P.; Langenaeker, W.; De Proft, F.; Baeten, A. Molecular electrostatic potentials vs. DFT descriptors of reactivity. In Molecular Electrostatic Potentials: Concepts and Applications. Theoretical and Computational Chemistry; Politzer, P., Maksic, Z.B., Eds.; Elsevier Science B.V.: Amsterdam, The Netherlands, 1996; Volume 3, pp. 587-617. 
30. Clinical and Laboratory Standards Institute. Performance Standards for Antimicrobial Susceptibility Testing; M100-S22; CLSI: Wayne, PA, USA, 2012.

31. Frisch, M.J.; Trucks, G.W.; Schlegel, H.B.; Scuseria, G.E.; Robb, M.A.; Cheeseman, J.R.; Scalmani, G.; Barone, V.; Mennucci, B.; Petersson, G.A.; et al. Gaussian 09; Gaussian, Inc.: Wallingford, CT, USA, 2009.

32. Lee, C.; Yang, W.; Parr, R.G. Development of the Colle-Salvetti correlation-energy formula into a functional of the electron density. Phys. Rev. B 1998, 37, 785-789. [CrossRef]

33. Becke, A.D. Density-functional thermochemistry. III. The role of exact exchange. J. Chem. Phys. 1993, 98, 5618-5652. [CrossRef]

34. Becke, A.D. Density-functional exchange-energy approximation with correct asymptotic behavior. Phys. Rev. A 1998, 38, 3098-3100.

35. Flukiger, P.; Luthi, H.P.; Portmann, S.; Weber, J. MOLEKEL 4.0; Swiss Center for Scientific Computing: Manno, Switzerland, 2000.

Sample Availability: Samples of the compounds are available from the authors.

(C) 2018 by the authors. Licensee MDPI, Basel, Switzerland. This article is an open access article distributed under the terms and conditions of the Creative Commons Attribution (CC BY) license (http://creativecommons.org/licenses/by/4.0/). 